\title{
船員の静電気防止具着用に関する基礎的研究
}

\author{
山本 一誠*

\section{Basic Study on Donning Personal Antistatic Devices for Seafarers}

\section{Kazusei YAMAMOTO}

\begin{abstract}
ISGOTT $^{(1)}$ says that," Experience over a very long period indicates that electrostatic discharges caused by clothing and footwear do not, however, present a significant hazard in the oil industry. This is especially true in a marine environment where surfaces rapidly become contaminated by deposits of salt and moisture that reduce electrical resistances, particularly at high humidity." and "An increasing number of items manufactured from synthetic materials are being offered for use on board ships. It is important that those responsible for their provision to tankers should be satisfied that, if they are to be used in flammable atmospheres, they will not introduce electrostatic hazards." Then the author heard what a seafarer and a land personnel with personal antistatic devices in a tanker discharged.
\end{abstract}

In this paper, the consciousness about seafarer's static electricity by the questionnaire was investigated, and the seafarer's electrostatic potential on tankers was measured.

The obtained results are summarized as follows:

(1) Human-body electrostatic potential is about $0 \mathrm{v}$ with personal antistatic devices, however, it is rarely about 1 $\mathrm{kV}$.

(2) Although antistatic measures are implemented by tankers, the two-thirds questioners has felt the static electricity inboard.

(3) Antistatic measures are carried out on all tankers by antistatic apparatus and personal antistatic devices.

Keywords : Static, antistatic, Seafarer

キーワード: 静電気, 静電気防止, 船員

\section{1. はじめに}

\section{1 研究の目的}

本研究は、タンカーで、静電服を着用していたに も係らず、船員および陸上職員から放電するのを見 たとの言葉より、その事実を確認するとともに、船 員の静電気に対する認識及び静電気防止具の活用及 びその効果の現状を明らかにするものである。

タンカーの発達は著しく、それとともにそれら船 上で働く者の静電防止服の発達も著しい。当初の静 電服は、金属線を縫いこんだものであったが、現在 では導通性の化学緎維で作られている。それら静電
服は着用者のニーズに合わせて作られたが、その下 に着用するものは、危険物等を運び始めた当初の綿 であるという慣習は守られているか否かは明白でな い。また、 International Safety Guide for Oil Tankers and Terminals ${ }^{(1)}$ には、石油産業界での長期にわたる経験 によれば、衣類や履物による静電放電は大きな危険 ではないことが判明している、及び船上における合 成繊維製品の使用は増加し、船内での静電気の危険 が発生しないことを確認する必要があると述べられ ている。

しかし、人体帯電がタンカーでの危険要因の一つ 
であることは否めない。

Table 1 Human-body electrostatic potential and Electric shock

\begin{tabular}{|c|c|}
\hline $\begin{array}{l}\text { Human-body } \\
\text { electrostatic } \\
\text { potential } \\
(\mathrm{kV})\end{array}$ & Electric shock \\
\hline 1.0 & A static shock is not felt at all. \\
\hline 2.0 & $\begin{array}{l}\text { Although a static shock is felt for } \\
\text { the point of a finger, it is not } \\
\text { painful. }\end{array}$ \\
\hline 2.5 & $\begin{array}{l}\text { A static shock is not painful, } \\
\text { although it is thought that a needle } \\
\text { touches and the point twitches. }\end{array}$ \\
\hline 3.0 & $\begin{array}{l}\text { It is thought painful that a static } \\
\text { shock is stabbed with a needle. }\end{array}$ \\
\hline 4.0 & $\begin{array}{l}\text { A static shock is thought to have } \\
\text { been deeply stabbed with the } \\
\text { needle, and has a pain in a finger } \\
\text { faintly. }\end{array}$ \\
\hline 5.0 & $\begin{array}{l}\text { A static shock is painful from a } \\
\text { palm to a fore-arm. }\end{array}$ \\
\hline 6.0 & $\begin{array}{l}\text { A static shock makes a finger } \\
\text { painful strongly and impresses a } \\
\text { brachium heavy. }\end{array}$ \\
\hline 7.0 & $\begin{array}{l}\text { A static shock gives a pain strong } \\
\text { against a finger and a palm, and } \\
\text { gives numbness. }\end{array}$ \\
\hline 8.0 & $\begin{array}{l}\text { A static shock gives numbness } \\
\text { from a palm to a fore-arm. }\end{array}$ \\
\hline 9.0 & $\begin{array}{l}\text { A static shock gives a pain strong } \\
\text { against a wrist, and gives the } \\
\text { weight numbed to the hand. }\end{array}$ \\
\hline 10.0 & $\begin{array}{l}\text { A static shock gives the sensibility } \\
\text { into which the pain and the } \\
\text { electricity flowed to the whole } \\
\text { hand. }\end{array}$ \\
\hline 11.0 & $\begin{array}{l}\text { A static shock makes it a finger } \\
\text { numbed strongly, and impresses } \\
\text { numbness strong against the whole } \\
\text { hand. }\end{array}$ \\
\hline 12.0 & $\begin{array}{l}\text { A static shock gives the sensibility } \\
\text { which hits the whole hand hard. }\end{array}$ \\
\hline
\end{tabular}

$※$ The capacitance of Human-body : approx. 100 pF
そこで、船員の静電気に関する意識および静電防 止具の活用の調查を行い現状を明らかにするととも に、さらに、静電気防止具の効果を帯電電位を測定 することにより、静電気災害防止の一助とする。残 念ながら、船舶での带電電位の放電を確認するには 至らなかったが、若干の知見が得られたので報告す 万。

\section{2 静電気放電の危険性 ${ }^{(2)}$}

带電した船員が、甲板上、ハンドレールやカーゴ ハッチ等の金属に接近した場合、人体に蓄積されて いた静電気は指先等から放電する。人体は静電気的 には、導体とみなされるので、放電時には蓄積され ていた静電気エネルギ一の全てが瞬間的に放出され る。このため、帯電した船員からの放電は電撃や放 電火花によるベントからの可然性ガスへの着火等の 火災・爆発を引き起こす恐れがある。

带電した人体からの放電による電撃の発生限界は、 人体の静電容量がほぼ一定とみなされる場合には、 人体の帯電電位によってあらわすことができ、人体 静電容量を約 $100 \mathrm{pF}$ の場合に扮ける人体带電電位と 電擊の強さと関係は Table 1 のとおりである。

Table 2 Minimum ignition energy of typical gases ${ }^{(3)}$

\begin{tabular}{|c|c|c|c|}
\hline \multirow[t]{2}{*}{ Substance } & \multicolumn{2}{|c|}{$\begin{array}{c}\text { Explosion } \\
\text { Limit } \\
(\text { Vol. } \%)\end{array}$} & \multirow{2}{*}{$\begin{array}{c}\text { Minimum } \\
\text { Ignition } \\
\text { Energy } \\
(\mathrm{mJ})\end{array}$} \\
\hline & U.E.L. & L.E.L. & \\
\hline Hydrogen & 4 & 75.6 & 0.019 \\
\hline Acetylene & 1.5 & 82 & 0.019 \\
\hline Ethylene & 2.7 & 36 & 0.096 \\
\hline Methanol & 5.5 & 44 & 0.14 \\
\hline Acrylonitrile & 2.8 & 28 & 0.16 \\
\hline Benzene & 1.2 & 8 & 0.2 \\
\hline Hexane & 1.1 & 7.5 & 0.24 \\
\hline Butane & 1.5 & 8.5 & 0.25 \\
\hline Ethane & 3 & 15.5 & 0.25 \\
\hline $\mathrm{LPG}$ & 2.1 & 9.5 & 0.25 \\
\hline Methane & 5 & 15 & 0.28 \\
\hline Acetaldehyde & 4 & 60 & 0.376 \\
\hline Ethyl acetate & 2 & 11.5 & 0.46 \\
\hline Acetone & 2.1 & 13 & 1.15 \\
\hline Toluene & 1.2 & 7.1 & 2.5 \\
\hline
\end{tabular}

静電容量 $\mathrm{C}(\mathrm{F})$ のコンデンサが $\mathrm{V}(\mathrm{V})$ の電圧で充電 されたときに蓄積される静電気エネルギ一W(J)は、

$$
\mathrm{W}=\frac{1}{2} \mathrm{CV}^{2}
$$


で示される。いま、船員が $1 \mathrm{kV} に$ 帯電している場合、 船員に蓄積されている静電気エネルギ一 $W_{1}$ を、人体 静電容量を $100 \mathrm{pF}$ として算出すると、 $\mathrm{W}_{1}=0.05(\mathrm{~mJ})$ となる。

主だったガスの最小着火エネルギーを Table 2 に しめす。この数值 $\mathrm{W}_{1}$ は Table 2 の水素ガスの最小着 火エネルギーを上回っている。つまり、水素ガスや アセチレンガスが漂っている大気において、着火に 適した混合気のある場合には、1kVに带電していた 船員からの放電により着火の恐れがある。

\section{2. 船員の静電気に関する意識調査}

乗組員の静電気に関する意識調査をするために、 アンケート用紙ファイルを船会社および連航管理会 社に送信し、船舶等から回答を受信した。平成 23 年 1 月から 3 月までの調查で、379 件の回答が得ら れた。

Table 3 Questionaire

\begin{tabular}{|l|}
\hline (1) Date \\
\hline (2) Male/Female \\
\hline (3) Age \\
\hline (4) Deck/Engine/Others \\
\hline (5) Cargo \\
\hline (6) LOA \\
\hline (7) GT \\
\hline (8) Dress under job \\
\hline (9) Dress when free \\
\hline (10) What do you consider about a static electricity? \\
\hline (11)Do you worry about a static electricity? \\
\hline (12) Where do you worry about a static electricity? \\
\hline (13) Have you felt the static electricity onboard? \\
\hline (14) When did you feel the static electricity? \\
\hline $\begin{array}{l}\text { (15) What are you keeping in mind to prevent of static } \\
\text { electricity? }\end{array}$ \\
\hline
\end{tabular}

アンケートの内容は Table 3 のとおりで、回答が自 由記入であったことから、テキストマイニングによ り、集計した。

回答者は Fig.1のとおりで、50 代、20 代、40 代、 30 代、60 代の年齢構成であった。さらに、Fig.2 か らわかるように4 分の 3 近くが甲板部であった。貨 物は Fig.3 に示すように、石油類が大半を占めてお り、アンケート配布先が大半タンカ一運航会社であ ったためである。回答者の乗船している船舶の大き さは Fig.4に示すと㧍りで、総トン数 $500 \mathrm{t}$ 以上 $1600 \mathrm{t}$

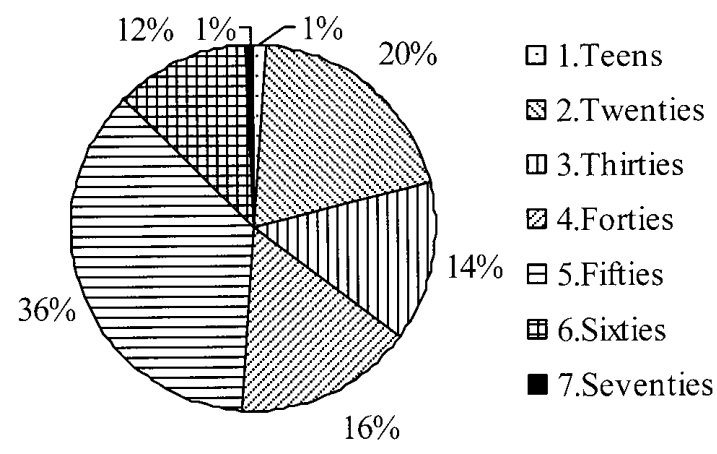

末満、3000t 以上 $5000 \mathrm{t}$ 末満が大半を占めた。

Fig.1 Questioner's Age

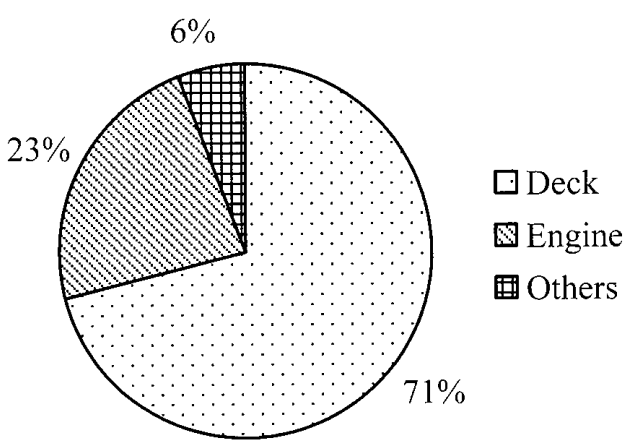

Fig.2 Questioner's Group

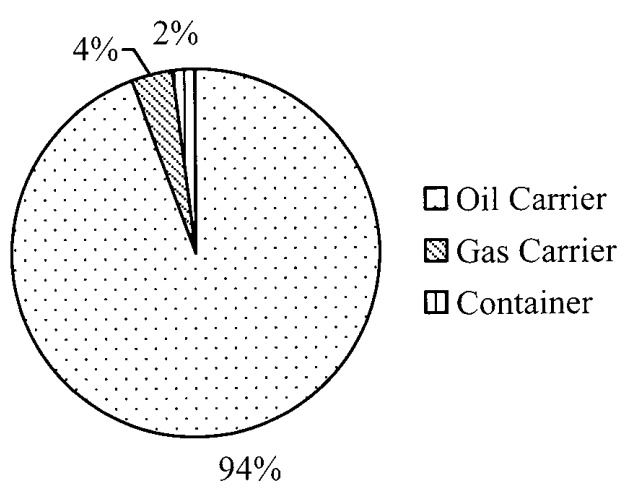

Fig.3 Cargo

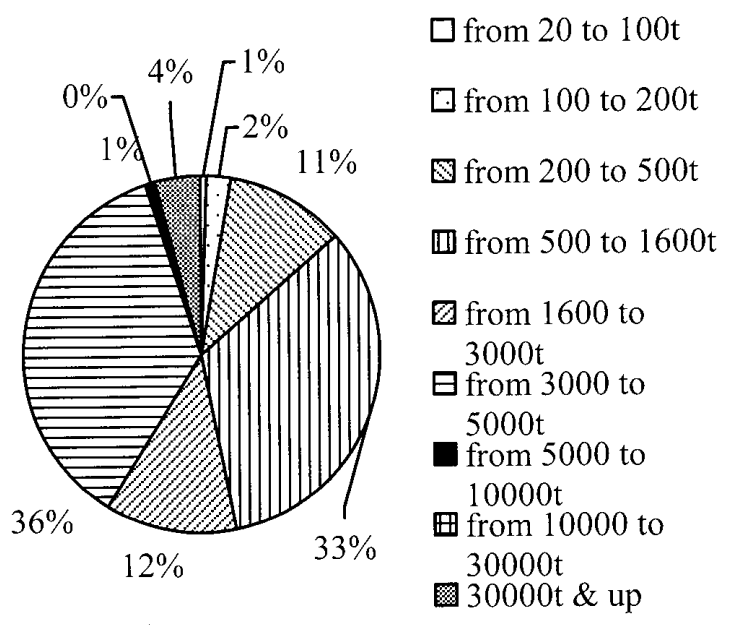

Fig.4 Questioner's Ship Size 


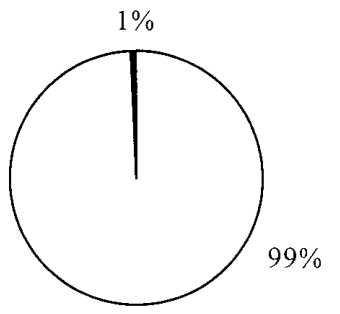

under job

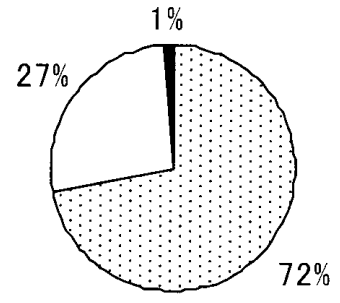

when free $\square$ Sportswear

$\square$ Personal Antistatic Devices

Others

Fig.5 Dress under job \& when free

作業中及び作業外の服装は、Fig.5 に示すように、 作業中は静電気帯電防止作業服及び静電気帯電防止 安全靴（以下、静電服等という。）着用し、作業外 では、およそ $70 \%$ がジャージ等のスポーツウェアを 着用、静電服のままという者もいるようである。

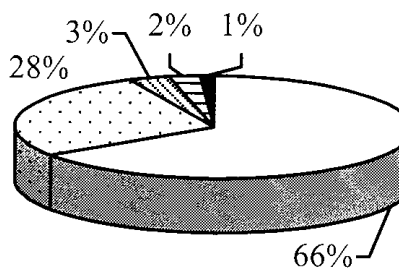

\section{$\square$ Fire \\ Explosion \\ $\square$ Static \\ 몽 \\ 曰Climate}

Fig.6 What do you consider about a static electricity?

アンケート100「静電気について何を連想するか」 の回答を Fig.6 に示す。火㷋・爆発が 66\%を占め、 次いで $28 \%$ が静電気そのものと回答していた。回答 文において性、火災・爆発は、火災、爆発、火花、 発火、着火、スパーク、引火、暴発のような語句を、 静電気は、電気、放電、痛い、ビリ、パチ、感電、 雷、稲光、ピリ、パチパチ、光、ビリッ、ビリビリ、 バチッ、走る、摩擦、しびれ、流れる、開ける、車、 高電流、除電、アース、指先、脱ぐ、セーター、下 敷きのような語句、告険は危険、気候は、乾燥、冬、 寒いのような語句を集計した。

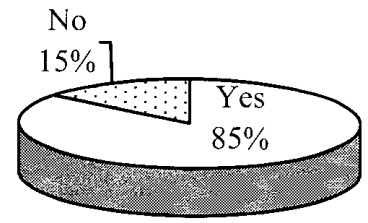

Fig.7 Do you worry about a static electricity?

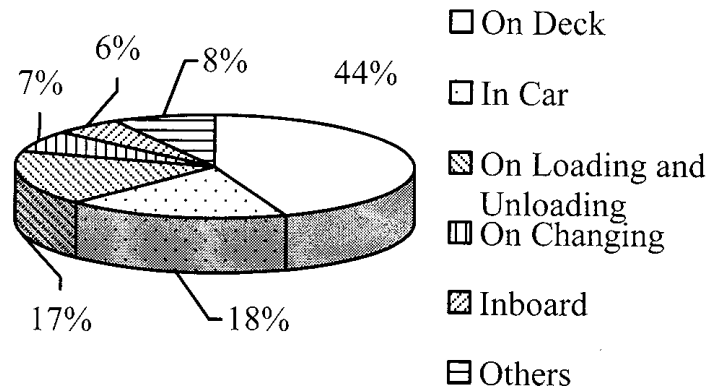

Fig.8 Where do you worry about a static electricity?

アンケート(11)静電気を気にするか、気にする場合 はアンケート112でそれはどこで気にするかを、Fig.7 およびFig. 8 に示す。 $85 \%$ が静電気を気にし、その場 所は、甲板上、車、荷役中と回答している。車は别 にして、Fig.6で火災・爆発と連想する者が多かった が、その可能性の多い場所である甲板上および荷役 中の回答が多い。

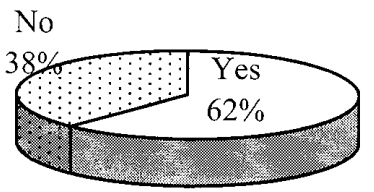

Fig.9 Have you felt the static electricity onboard?

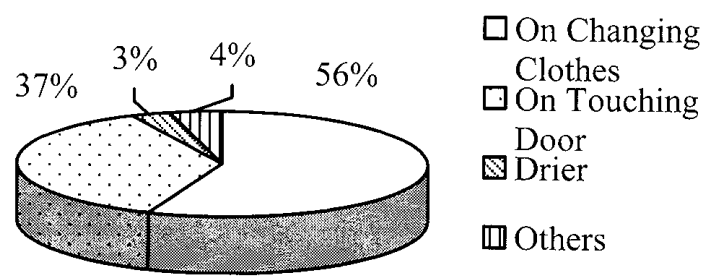

Fig. 10 When did you feel the static electricity?

アンケート113の「静電気を船上で感じたことがあ るか」、感じた場合はアンケート(14)で「それはどのよ うな場合に感じたか」を、Fig.9およびFig.10に示す。 $62 \%$ が船上で静電気を感じているが、回答者のほと んよ゙が石油類を運んでいることを鑑みると火災や爆 発を引き起こすのではないかと思われる。 


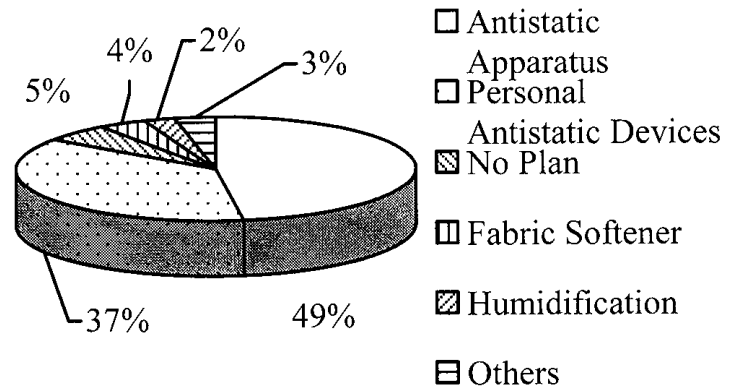

Fig.11 What are you keeping in mind to prevent of static electricity?

アンケート(15)の「静電気防止のために心がけてい ること」をFIg.11 に示す。静電気防止具が 49\%、静 電服等が $37 \%$ 、特に無し、柔軟剂、加湿となってい る。静電気防止具は、静電気除去シート、静電気除 去バー、静電気除去板、除電板、除電、アース、放 電、バー、シート、握る、触る、さわる、ステン レス、水道のような語句を、静電服等は、静電衣、 静電服、作業服、綿、衣類、服、着る、着用、化学 繊維、ナイロン、セーター、毛糸、化学製品、ナイ

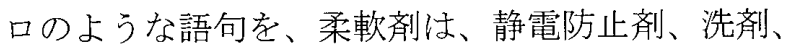
洗濯用柔軟凨の名称、柔軟剂のような語句を、加湿 は、乾燥、湿度、加湿、水のような語句を集計した。 静電気防止に洗濯用柔軟剤と回答しているところが、 船員が身近なところから安全に取り組んでいること が伺える。

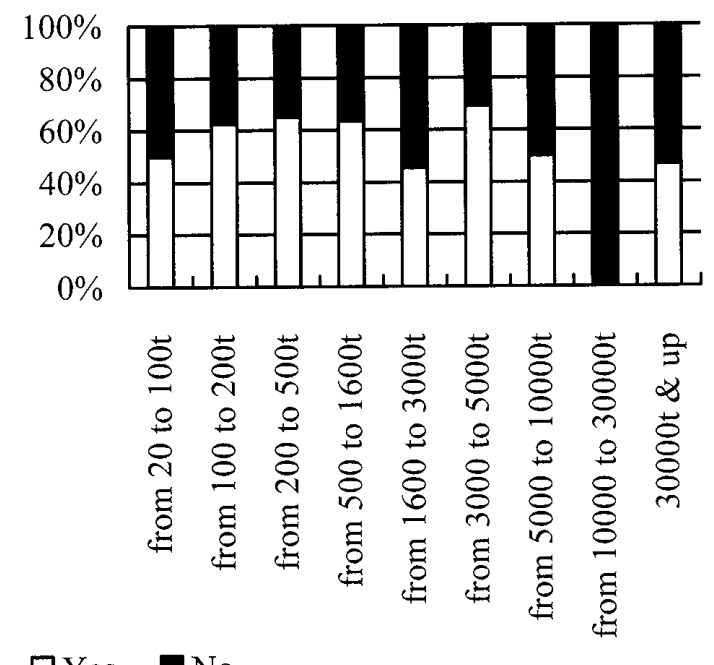

$\square$ Yes $\square$ No

Fig.12(a) Correlation between "Have you felt the static electricity onboard?" and Questioner's Ship Size

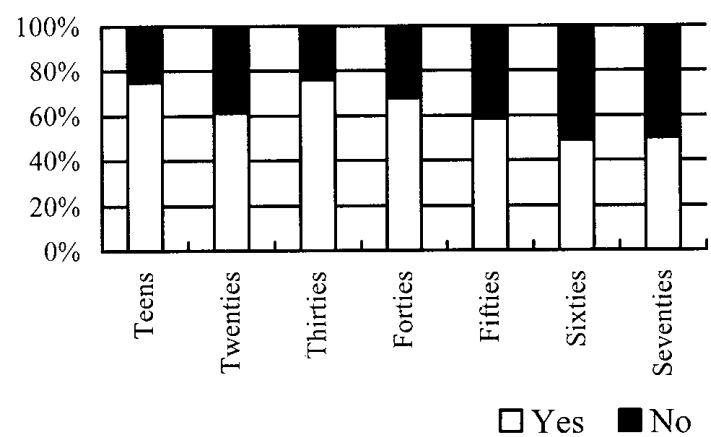

Fig.12(b) Correlation between "Have you felt the static electricity onboard?" and Questioner's Age

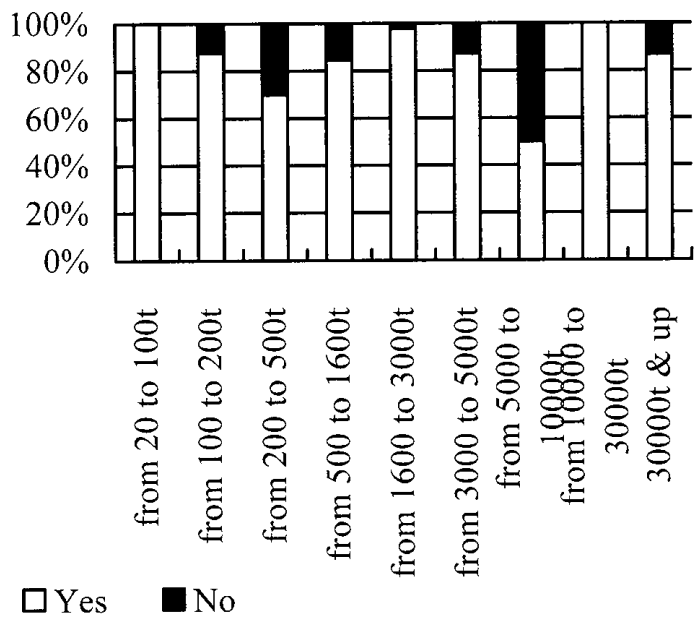

Fig.13(a) Correlation between "Do you worry about a static electricity?" and Questioner's Ship Size

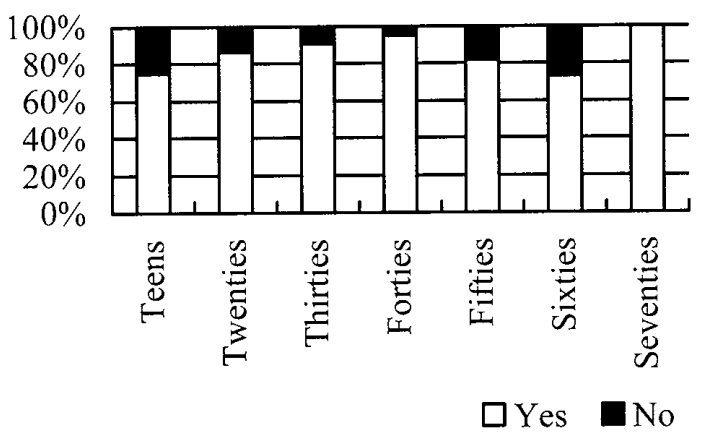

Fig.13(b) Correlation between "Do you worry about a static electricity?" and Questioner's Age

アンケート113)「静電気を船上で感じたことがある か」と船舶の大きさおよび年齢との相関を Fig.12(a)(b)に示す。10000 トンから 30000 トンでは 
回答数が少ないので別として、ほとんどの大きさの 船舶で、半数は静電気を感じておう、年齢について も同様に静電気を感じている。年齡においては、高 齢になるほど静電気を感じる数が少なくなっている。

また、アンケート(11)「静電気を気にするか」と船 舶の大きさおよび年齢との相関をFig.13(a)(b)に示す。 船舶の大きさにおいては 200t 以上 $500 \mathrm{t}$ 末満と $5000 \mathrm{t}$ 以上 $10000 \mathrm{t}$ 末満に近づくと若干ではあるが静電気 を気にせず、年齢においては、10 代から 40 代一と 静電気を気にするが増え、40 代から減るという傾向 を示している。

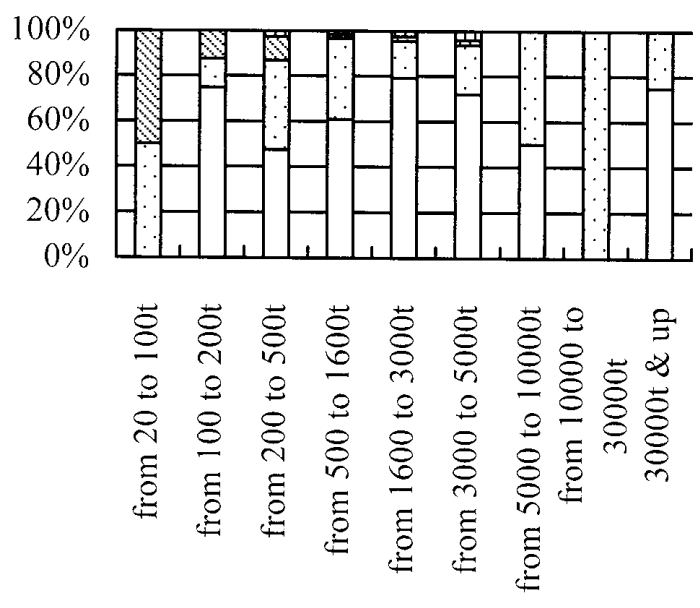

$\square$ Fire Explosion $\square$ Static $\mathbb{S}$ Danger $\square$ Climate

Fig. 14(a) Correlation between "What do you consider about a static electricity?" and Questioner's Ship Size

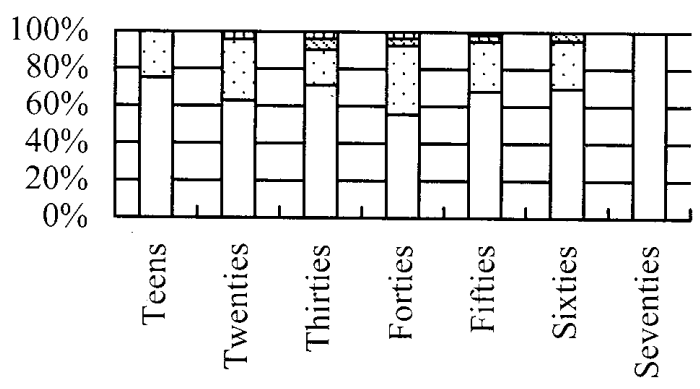

$\square$ Fire $\cdot$ Explosion $\square$ Static $⿴$ Danger $\mathbf{\square}$ Climate

Fig. 14(b) Correlation between "What do you consider about a static electricity?" and Questioner's Age

さらに、アンケート(10)「静電気について何連想 するか」と船舶の大きさ抢よび年齢との相関を Fig.14(a)(b)に示す。船舶の大きさにおいては、火災・
爆発、静電気及び危険の割合が $100 t$ 以上 $10000 t$ 未 満でその割合に傾向は見出せないが、火災・爆発の 割合が多い。100t 未満、10000t 以上 $30000 \mathrm{t}$ 未満では 火災・爆発を連想していない。年齢ではいずれの年 齢でも火㷋・爆発を $60 \%$ 以上が連想し、ついで静電 気を連想している。

最後に、アンケート(15)「静電気防止のために心が けていること」と船舶の大きさおよび年齢との相関 を Fig.15(a)(b)に示す。10000t 以上 30000t 未満では特 に無しとあるは、コンテナ船であることが推察され る。 $5000 t$ 以上 10000 未満に加湿が半数を占めてい る。

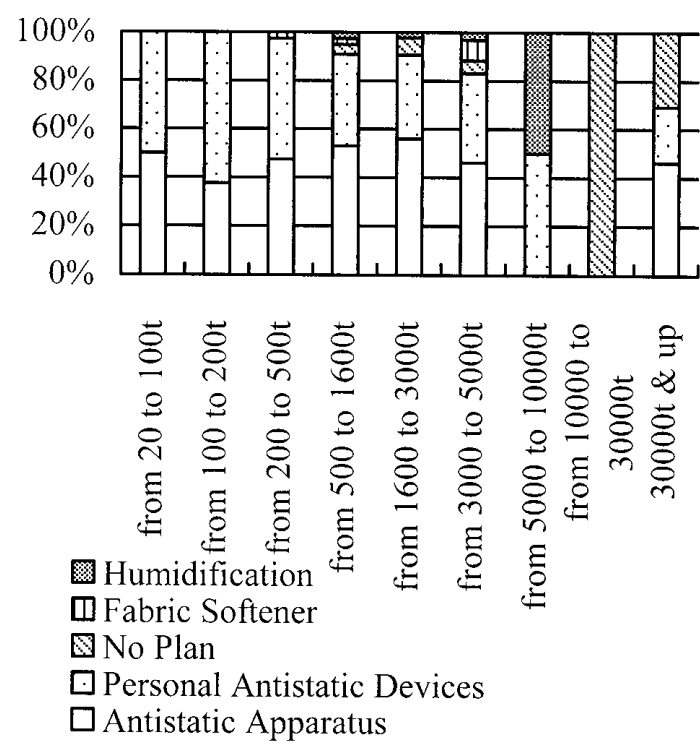

Fig.15(a) Correlation between "What are you keeping in mind to prevent of static electricity?" and Questioner's Ship Size

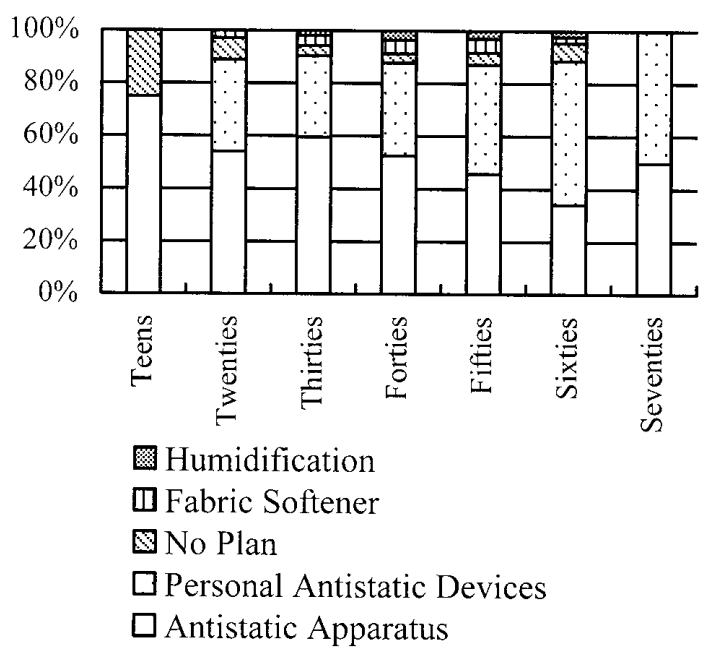

Fig.15(b) Correlation between "What are you keeping in mind to prevent of static electricity?" and Questioner's Age 
高齢になるほど静電気防止具より静電服等の着用 の割合が増えており、特に無しが各年齢若干あり、 静電気防止を心がけない者のいることが危惧される。

Fig.12 から Fig.15 において、船舶の大きさおよ び年齢との相関をとったことは、調査項目について 顕著な傾向が得られると推察したことによる。つま り、船舶の大きさにおいては、貨物油量や油種によ る静電気災害のリスクから、大きな船舶ほど静電気 について過度な反応があり、年齢においては、その 経験年数から高齢者ほど過度な反応が予想されるも のと考えたが、顕著な傾向が得られなかった。船員 の静電気への恐れや静電気防止具活用の動機付けを 明らかにすることが目的に含まれていたのであるが、 前述のように顕著な傾向は得られなかった。この理 由として推察すると、船員は静電気に関する教育及 び指導を随時受けていることをあげることができる であるう。

\section{3. 内航タンカーにおける船員の帯電電位}

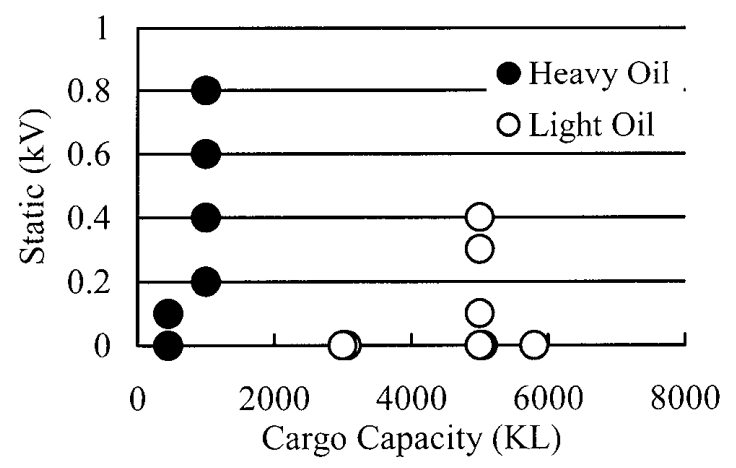

Fig.16 Human body electrostatic potential on deck in Coastal Oil tankers

平成 23 年 2 月、千葉県市原市の某精油所栈橋係 留中の内航タンカ一甲板上で、船員の静電気帯電電 位を静電メーター(春目電機、KSD1000)にて測定し た。船員 29 名から協力を得られ、Fig.16に、積載容 量を横軸に、静電気帯電電位を表示した。○は白油、 つまり、ガソリンやナフサなどの精製油を、○は黒 油、つまり、重油や潤滑油を貨物としているタンカ 一である。船員は全員静電服等着用で、その下には 綿素材のものを着用していた。彼らの中には合成纎 維のシャツやネックウォーマーを着用している者も いた。

測定した結果、静電気带電電位はほとんどの者が $0 \mathrm{kV}$ であったが、白油タンカーと黒油タンカーでは 船員の帯電電位に異なる傾向があった。これは、白
油は引火点が低く、火災爆発の仜険性が高いもので あり、黒油は引火点が高く、火災爆発の危険性が低 ものであるとした貨物油に対する船員の注意が異な るであろうことからと推察する。また、5000KL 積 み GT3500t の船舶では最大 $0.4 \mathrm{kV} 、 1000 \mathrm{KL}$ 積み GT499tの船舶では最大 $0.8 \mathrm{kV}$ が測定された者がいた。 これらの数值を式(1)により静電気エネルギーに換 算すると、 $0.4 \mathrm{kV}$ では $0.008 \mathrm{~mJ} 、 0.8 \mathrm{kV}$ では $0.032 \mathrm{~mJ}$ と計算された。Table 2 を参照すると水素やアセチレ ンが大気中にあれば引火の可能性があると推察され た。

\section{4. まとめ}

船員の静電気防止具着用に関する基礎事項を調查 するにあたり、アンケートによりその現状を調査し、 静電服等の効果を静電メータにより、船舶上におい て船員の静電帯電電位を測定した。本研究により得 られた結果を要約すると以下の通りである。

(1) 静電服等を着用していれれば、静電気帯電電 位はほぼ $0 \mathrm{~V} て ゙ あ る か ゙ 、 1 \mathrm{kV}$ 近く帯電する場合があ る。

（2）静電気防止対策が施されているた現状では あるが、回答者のおよそ 3 分の 2 が船内で静電気を 感じている。

（3）船員の静電気に関する意識は船の大きさお よび年齢について顕著な傾向は現れなかった。この ことは静電気に関する教育及び指導が随時なされて いるものと推察される。

今回、人体の静電容量を $100 \mathrm{pF}$ で計算したが、こ の值が適当であるかどうかを調查する必要がある。 さらに、内航タンカーでは、取り扱う石油類により ブタン、エタン、プロパン等がベントから放出され ている場合があり、それらの最小着火エネルギ一か ら帯電電位を式(1)により導くと $2.2 \mathrm{kV}$ となる。つま り、人体に感じるような放電をした場合引火となる 恐れがある。さらに、静電服の下に着用する物につ いては調査しなかったが、この電位が発生するよう な場合が現在の機能的下着の組み合わせにより発生 する可能性を否定することはできないので、さらに 調查する必要がある。

\section{5. 謝辞}

本研究を進めるにおいて、アンケートにご協力い ただいた方々に、特に旭タンカー株式会社千葉駐在 事務所長三木繁雄氏、同安全管理部竹谷和男氏には 多大なるご助言ご指導頂き、深く感謝致します。 


\section{6. 参考文献}

(1) ICS/OCINF/IAPH : International Safety Guide for Oil Tanker and Terminal 5th ed, P.62,Witherbys Publishing, 2006

（2）村田雄司他 15 名：帯電の測定方法と静電気障 害対策, pp.189-197, サイエンス\&デクノロジ 一, 2008.11

（3）小野雅司：人体の带電危険とその防止，静電気 学会誌 Vol.15, No.2（障災害防止）、1991、 pp.125-133, 静電気学会誌 Vol.15, No.2（障災 害防止）,1991

\section{7. 質疑応答}

堀晶彦（海技大学校）:

実測結果の中で、白油の場合、黒油の場合で、值 が異なっているが、この結果は何か船員の取り組 みとの関係があるのでしょうか。

山本一誠：

本研究からは、推察できません。

笹健児（広島商船高等専門学校）:

アンケート項目のいくつかで 10000～30000トン の船舶が他の大きさの船舶の調査結果と異なる傾 向が出ていると考えられますが、船種その他で何 らかの景況があるのかその点がお分かりでしたら 教えてください。

山本一誠 :

データ数の関係から詳細な検討をしていませんの で、今後の検討課題としま寸。

藤本昌志 (神戸大学) :

内航船では甲板上よりも船内での静電気を感じる とのアンケート結果ですが、内航船では船内の圧 力が外気と同様であればガス流入があった場合危 険と思いますが、船内での静電気の防止について ハード、ソフト面でどのような対策等が考えられ ますか。

山本一誠 :

船舶安全法及び ISGOTT 遵守から、ハード面では 出入り口にガス検知器、ソフト面では荷役中調理 用火気厳禁等がとられています。 